\title{
ANALYSIS OF THE FACTORS AFFECTING THE QUALITY OF THE CHEMICAL AND MICROBIOLOGICAL DRINKING WATER AT THE DEPOT DRINKING WATER REFILL TULUNGAGUNG DISTRICT
}

\author{
EKA PUSPITASARI \\ Graduate Studies Program Stikes Surya Mitra Husada Kediri
}

\begin{abstract}
Refill drinking water Depot is an industry that does the processing of the raw water into drinking water and sell directly to the consumer. Mn metal and bacterial Coliform is an indicator of refill drinking water polluters. This research aims to find the factors influencing the quality of Microbiology and chemistry at the depot drinking water drinking water refill Tulungagung district. Research using survey method with Cross sectional approach is analytical. The sampling technique used was Simple Random Sampling with a sample of 89 depot drinking water refill. Technique of data analysis using Regression and Logistic regression test linear. Independent variable examined was the source of raw water, the depot operator hygiene of drinking water, hygiene, sanitation, which covers three aspects namely sanitary location, building and facility sanitation. The results showed from 89 depot examined known as much as $79.8 \%$ sanitation facilities are not qualified, the value of the MPN 59.55\% of eligible and levels of Mn 100\% qualified. From Regresilogistik test results between independent variable with the value of the MPN indicate significance of $0.008<(\alpha=0.05)$ on sanitation facilities are variable. This means there are influences between facilities sanitation microbiological quality of drinking water. On Linear regression test results between independent variable with the value obtained significance levels of Mn $0.47>((\alpha=0.05)$ which means no influence between independent variables with the chemical quality of drinking water. The lack of sanitation facilities increases the potential for bacterial contamination through the operator. Therefore the availability of on-site sanitation depot drinking water is a major factor that affects the quality of drinking water microbiology refills.
\end{abstract}

Key word: Depot drinking water, hygiene and sanitation, hygiene, raw water source of the operator, the value of the MPN, manganese (Mn). 


\section{A. Background}

Clean water is the most important basic needs and very sensitive in people's lives, as well as being one of the basic necessities for the community. In general the problem of clean water can be divided into three issues, namely the qualitative, quantitative and continuity (Firmanasari, 2015). In urban areas and in rural areas, the current drinking water needs can be met by consuming drinking water in containers (AMDK), because it is considered more practical and more hygienic. Refill drinking water Depot (DAMIU) is an industrial raw water treatment process into drinking water and sell directly to the consumer. In East Java, there are as many as 5,924 depot refill drinking water that is not decent sanitary hygienic certificate pocketed from the East Java Health Office. Of the 6,000 depot drinking water refills, only 76 pocketed only setifikat. It is feared there are microbiology and chemical elements contained in drinking water is not worth consuming. Metal $\mathrm{Mn}$ is one of the very large amount of metal in the soil, in the form of oxides or hydroxides. MN sourced from human activities can enter the environment of water, soil, air and food. Microbiological parameters determined by conducting an examination of Coliform bacteria, E-coli and pathogenic bacterial species. Fecal Coliform bacteria there, e.g. E-coli, indicating that there has been contamination with fecal waste. In Tulungagung district around 116 DAMIU registered in the health service as many as 32 samples taken Tulungagung, DAMIU and the result as much as $25 \%$ of the water processed be bacteriologically examination are not eligible. The presence of Coliform bacteria may be caused by contamination of raw water, the type of equipment used, maintenance tools, handling water processed results and employees.

\section{B. Research methods}

Based on the type, this research using survey method of analytic approach to Croos Sectional, where this research aims to study the dynamics of correlations between risk factors with effects, by the way approach, observation or data collection while at the same time. This means that each subject of study only observed once and measurements of the status or variable character of the subject at the time of the examination (Notoatmodjo, 2015).

\section{Results}

\section{MPN values of frequency distribution}

Table 1.1 distribution of Frequency values of the MPN In Tulungagung district drinking water Depot on 20 July - September 20, 2017

\begin{tabular}{llcc}
\hline & MPN Value & $\mathrm{n}$ & $(\%)$ \\
\hline a. & Eligible & 53 & 59,55 \\
\hline b. & Not Eligible & 36 & 40,45 \\
\hline
\end{tabular}

Source : Primary Research Data

Table 1.1 Note that 89 of the depot drinking water there are $53(59.55 \%)$ value of the MPN from the water processed in Tulungagung district drinking water depot has qualified

\section{Frequency distribution levels of Mn}

Table 1.2 Distribution levels of Mn In Tulungagung district drinking water Depot on 20 July - September 20, 2017

\begin{tabular}{lc}
\hline \multicolumn{2}{c}{ The level of Mn } \\
\hline Mean & 0,10 \\
\hline Minimum & 0,04 \\
\hline Max & 0,19 \\
\hline
\end{tabular}

Source: Primary Research Data

Data table 1.2 known levels of $\mathrm{Mn}$ in air results in processed drinking water depot in Tulungagung district averaged - averaged is $0.10 \mathrm{mg} / \mathrm{l}$. minimum levels of $\mathrm{Mn}$ water processed amounted to $0.04 \mathrm{mg} / \mathrm{L}$ and the maximum rate is $0.19 \mathrm{mg} / \mathrm{L}$ 
Journal for Quality in Public Health

Vol. 1 No. 1 Januari 2018

3. Cross-Tabulations Between Hygiene and sanitation With the value of the Processed Water MPN Depot drinking water

Table 1.3 Cross Tabulations Between Hygiene Sanitation With the value of the Processed Water MPN Depot drinking water Tulungagung district on 20 July - September 20, 2017

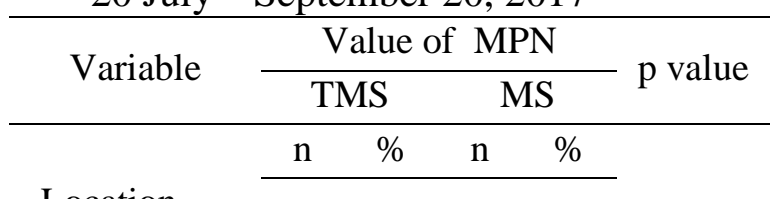

Location

sanitation

\begin{tabular}{cccccc} 
TMS & 31 & 46 & 36 & 54 & \multirow{2}{*}{0,05} \\
\cline { 1 - 4 } MS & 5 & 23 & 17 & 77 & \\
\hline Build & & & & &
\end{tabular}

\begin{tabular}{lccccc} 
TMS & 27 & 48 & 29 & 52 & \multirow{2}{*}{0,05} \\
\cline { 1 - 4 } MS & 9 & 27 & 24 & 73 & \\
\hline$y y y n n$
\end{tabular}

sanitation

facilities

$\begin{array}{lccccc}\text { TMS } & 35 & 49 & 36 & 51 & 0,001 *\end{array}$

* a statistically Meaningful with $p<0.05$

Source: Primary Research Data

Based on table 1.3 above note that the location of the sanitation depot qualified drinking water shows the value of the processed results of MPN water $77 \%$ qualified. In terms of the building, if the building drinking water depot qualify then the value of the processed water MPN depot drinking water also qualify $(73 \%)$. Viewed from a sanitation facilities sanitation facilities, if the depot drinking water qualify then the value of the processed water MPN depot drinking water would be eligible anyway $(94 \%)$. The Chi square test results from all three of these variables is obtained $p$ value 0.001 on the sanitation facilities variable means there is a connection between sanitation facilities with a value of processed water MPN depot drinking water.
p-ISSN: 2614-4913

e-ISSN: 2614-4921

4. Cross-Tabulations Between Raw water source with a value of Processed Water MPN Depot drinking water

Table 1.4 Tabulate cross between Raw water sources drinking water Depot is used With the value of the Processed Water MPN Depot drinking water Tulungagung district on 20 July -20 September 2017

\begin{tabular}{|c|c|c|c|}
\hline \multirow{3}{*}{ Variable } & \multicolumn{2}{|c|}{ Value of MPN } & \multirow{3}{*}{$\begin{array}{c}\mathrm{p} \\
\text { value }\end{array}$} \\
\hline & $\begin{array}{l}\text { TMS } \\
(\mathrm{n} \%)\end{array}$ & $\begin{array}{l}\text { MS } \\
(\mathrm{n} \%)\end{array}$ & \\
\hline & $\mathrm{n}$ & $\%$ & \\
\hline
\end{tabular}

The raw water

source

\begin{tabular}{|c|c|c|c|c|}
\hline Well Water & 4 & 57 & 3 & 43 \\
\hline Mountain & 32 & 39 & 50 & 61 \\
\hline
\end{tabular}

Source : Primary Research Data

Based on the table above 1.4 can be seen if the depot drinking water using raw water source of water the mountains then the value of the processed water MPN depot drinking water tend to be eligible i.e. amounting to $61 \%$. From the Chi square test results obtained $\mathrm{p}$ value 0.35 which means there is no relationship between the use of the raw water source with the value of the MPN.

5. Cross-Tabulations between the Depot Operator Hygiene of drinking water With the value of the Processed Water MPN Depot drinking water

Table 1.5 Cross Tabulations Between Operator Depot drinking water Hygiene With the value of the Processed Water MPN Depot drinking water Refill Tulungagung district on 20 July - September 20, 2017 
Vol. 1 No. 1 Januari 2018

\begin{tabular}{lccccc}
\hline \multirow{2}{*}{ Variable } & \multicolumn{4}{c}{ Value of MPN } & $\mathrm{p}$ \\
\cline { 2 - 4 } & \multicolumn{2}{c}{ TMS } & \multicolumn{2}{c}{ MS } & value \\
\hline \multirow{2}{*}{$\begin{array}{l}\text { Hygiene } \\
\text { operator }\end{array}$} & $\mathrm{n}$ & $\%$ & $\mathrm{n}$ & $\%$ & \\
\cline { 2 - 4 } TMS & 31 & 44 & 39 & 56 & \\
\hline MS & 5 & 26 & 14 & 74 & 0,16 \\
\hline
\end{tabular}

Source : Primary Research Data

Based on table 1.5 can be seen if the State of hygiene of drinking water depot operators qualify then the value of the processed water MPN depot drinking water tend to be eligible i.e. amounting to $74 \%$. From the Chi square test results obtained $\mathrm{p}$ value 0.16 which means there is no relationship between the operator's hygiene with a value of processed water MPN depot drinking water.

6. The results of the logistic regression test Between Independent Variables with the quality of Microbiology (MPN)

a. The dominant influence of the independent variable to the quality of the drinking water Microbiology (MPN)

Table 1.6 analysis of factors influencing the quality of Microbiology of water Drink In The Depot Drinking Water Refill Tulungagung Regency

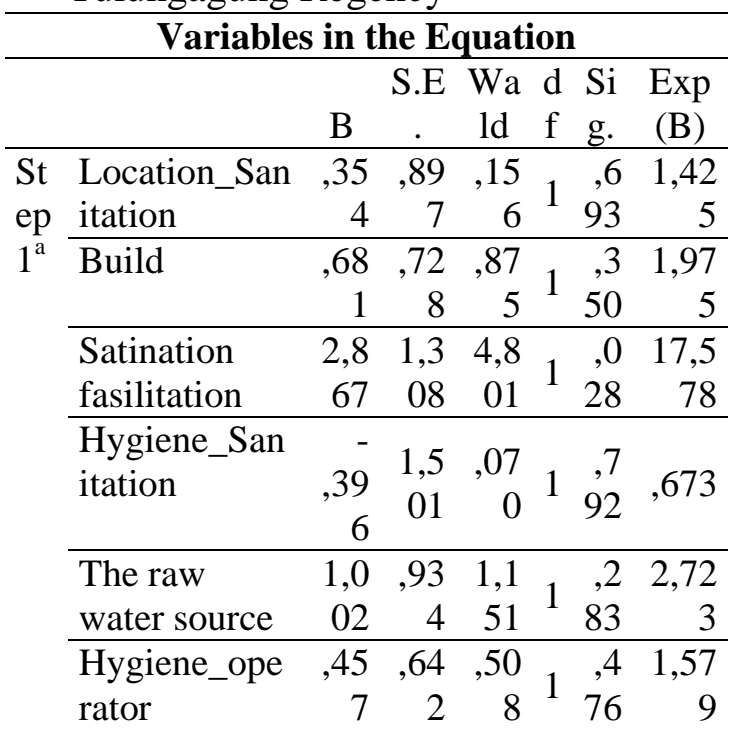

e-ISSN: 2614-4921

\begin{tabular}{lrrrrrr}
\hline Constant & - & 1,8 & 1,4 & &, 2 & \\
& 2,2 & 52 & 87 & 1 & 23 &, 105 \\
& 59 & & & & \\
\hline
\end{tabular}

a. Variable(s) entered on step 1: Location sanitation, Build, Sanitation fasilitation, Sanitation Hygiene, The raw water source, Hygiene operator.

Saource : Primary Research Data

Based on table 1.6 shows that of the six independent variables following the logistics regression test conducted only one variable that affects the quality of drinking water Microbiology at the depot drinking water refill Tulungagung district, namely, facilities sanitation $(\mathrm{p}=0.028$; Or $=17.578)$. This means that if the sanitation facilities don't qualify then the risk of microbiological quality of unqualified 17.578 times larger than sanitation facilities that qualify. So it can be concluded that the most dominant factor influencing the quality of Microbiology of drinking water sanitation facilities is a factor with the influence of 17.578 times.

7. Linear regression test Results Between Independent Variables With Chemical Quality (levels of Mn)

Table 1.7. Dominant Influence variables independent of the chemical quality of drinking water (levels of Mn)

\begin{tabular}{cccc}
\hline \multicolumn{2}{c}{ Coefficients $^{\mathbf{a}}$} & \\
\hline Unstan & Stand & & \\
dardize & ardize & & Collinea \\
$\mathrm{d}$ & $\mathrm{d}$ & & rity \\
Coeffic & Coeffi & & Statistic \\
ients & cients & S & $\mathrm{s}$ \\
\hline Std. & i & Tole V \\
Erro & g & ranc IF
\end{tabular}

\begin{tabular}{lllllll} 
Model & $\mathrm{B}$ & $\mathrm{r}$ & Beta & $\mathrm{t}$ &. & $\mathrm{e}$ \\
\hline 1 (Constant & & & & 3, &, & \\
) & 1 & & & 3 & 0 & \\
& 0 &, 030 & & 2 & 0 & \\
& 1 & & & 4 & 1
\end{tabular}


Vol. 1 No. 1 Januari 2018

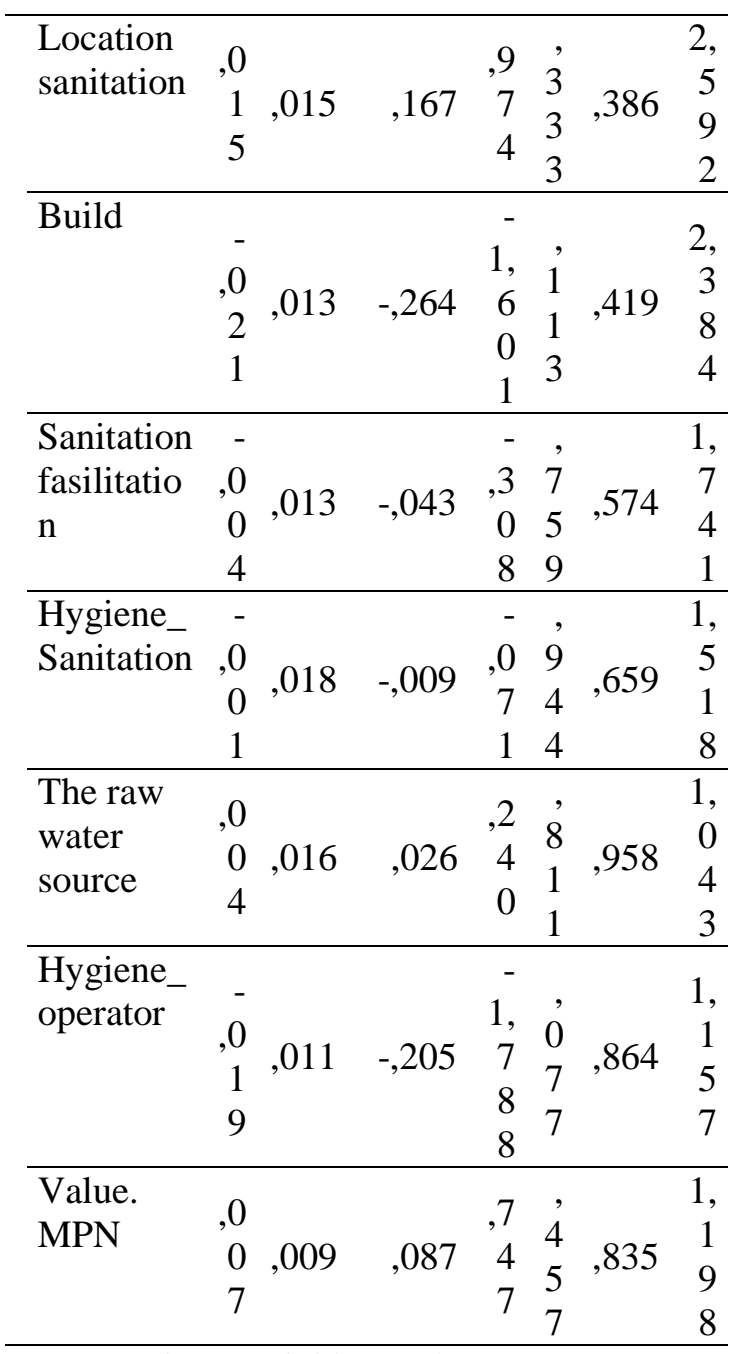

a. Dependent Variable: Kadar_Mn

Saource : Primary Research Data

Based on Table 1.7 shows that of the six independent variable linear regression test done after none of the variables that affect the chemical quality of drinking water in the depot drinking water refill Tulungagung district. This can be inferred by looking at the value of Sig which of the six independent variable value Sig $>0.05$.

\section{Discussion}

The main findings of this research is the availability of on-site sanitation is the most dominant factor influencing the quality of the drinking water microbiologically refills in Tulungagung district. This is evidenced from the results of statistical analysis with crosstabulations (bivariat) statistical analysis
e-ISSN: 2614-4921

and regression (Logistic Regression). The results of the statistical analysis tabulate sanitation facilities as a cross between an independent variable with the value of the dependent variable resulting MPN value of $0.001 \mathrm{p}$ while the results of the statistical analysis with logistic regression results are obtained in the form of There is only one variable that affects the quality of drinking water Microbiology at the depot drinking water refill Tulungagung district, namely sanitary facilities $(\mathrm{p}=0.028$; Or $=17.578)$. The calculation of the value of the MPN refill drinking water conducted by the method of Coliform MPN test and examined in the laboratory of the health area (Labkesda) Tulungagung district. Calculation of the parameters of the MPN are said to be eligible if in $100 \mathrm{ml}$ sample is not found Coliform MPN (Permenkes No. 43 Year 2014). This is in line with the classification of the WHO that mention that the levels of koliform on good water atauconformity is $0 \mathrm{cfu} / 100 \mathrm{ml}$ of sample. Many factors affect the quality of drinking water microbiologically refills, including aspects of Hygiene and sanitation consists of 3 factors, i.e. factors place/location, equipment and penjamah factors (Permenkes No. 43 Th 2014). Aspects of the places seen with at least 11 parameters, namely the location of the pollution-free area, building powerful and easy maintenance, waterproof floors, walls, roofing and waterproof ceiling is strong, has a door that is strong and durable, lighting pretty, good ventilation, the air humidity is comfortable, have access to basic sanitation facilities and free of carrier animals and vectors of disease. The results obtained in this study that only variables statistically sanitation facilities means of MPN DAM. This is not in line with the results of previous studies conducted in the city of Denpasar. Previous research by Sabariah (2016) mentions that many of the factors that affect the quality of drinking water microbiologically refills, including sanitation of raw water, the location, the 
process of disinfecting and sanitation facilities but that deal in the statistics are only a factor of sanitation site ( $\mathrm{p}$ value $=$ 0.000).

In this study showed a statistically meaningful sanitation facilities. Memilikifasilitas no sanitation in the form of hand-washing place, and or have a hand-washing but not equipped with running water and SOAP, so that its potential can be bacteriologically through contamination by operators who are not hygienic in beke that's like not washing tangansebelum serve consumers due to outage means washing his hands (Suriadi et.al., 2016). The difference in results of this research with some earlier research caused by weaknesses of this research. There are several weaknesses in this study, namely design and great samples. In the design of a cross-sectional study, exposure (exposure) and diseases (outcomes) measured simultaneously or concurrently on each of the subjects of the research. It is like we make a snapshot of the population at the same time. This resulted in the emergence of the limitations of the study, i.e. If there is a relationship between exposure and outcomes, the temporal nature of the relationship (Gordis, 2013). The second weakness comes from large samples. Researchers are trying to anticipate the onset of effect perancu by choosing engineering samples of Simple Random Sampling and has done a great sample calculation with a maximum error rate of $5 \%$ and a total population of 116 . However, the population of the DAM a number of 116 turns out does not represent the whole of the existing DAM in Tulungagung district.

Based on the observations of the researchers and the scientific search data from multiple news articles and there are still many DAMS that do not have a business license and no response in the health service. Data from the employers ' Association and the distribution of drinking water Supplier Indonesia
(APDAMINDO) mentions that three thousand of the depot drinking water spread area of Jabodetabek, only 20-30\% that already have permission from the Ministry of industry and be eligible to be consumed ( Online legal, 2013). Therefore research samples taken a number of sample population represents only 89 DAM that had been licensed in Tulungagung district so the withdrawal results conclusions cannot be generalized to the population in General in the region of DAM Tulungagung Regency. The limitations of the research on the chemical quality of drinking water chemical quality parameters are only viewed based on levels of $\mathrm{Mn}$. This is because it is not possible to test all components of the chemical in drinking water causes health problems. Nevertheless, we can prioritize to see the levels of some metals such as iron, manganese and hardness. High levels of manganese can cause neurotoksik effects (WHO, 2011 and Adelina et.al., 2012). The results of statistical analysis showed that all the factors the only Predictor can predict levels of chemical quality $\mathrm{Mn}$ of $7.6 \%$. This means $92.4 \%$ there are other factors which are not examined in this study.

The research indicates that levels of Mn were found from 89 DAM in Tulungagung district belongs to the categories of normal, i.e. does not exceed $0.4 \mathrm{mg} /$ litre (Permenkes No. 492 Th 2010). Measuring results against levels of $\mathrm{Mn}$ shows that the average levels of Mn from the sample water recharge in Tulungagung district is 0.100 .04 minimum value and maximum value of 0.19 and normal distribution of the data. This means there is no metal pollution Mn on drinking water refill. The absence of contamination metals Mn can also be proven from the water refills are not felt because of the high levels of the metal manganese is usually associated with high levels of iron so that on water recharge with a metal, it is certain that water high levels of iron and the levels 
of Mn (Adelina et.al., 2012). In this study there was no leaching of Mn levels caused by raw water sources used for water refills came almost entirely from the mountains in the area, namely Sendang, Tulungagung. Levels of Manganese (Mn) in the environment increased in line with the the increasing human activities and industrial, manganese sourced from human activities can enter the environment of water, soil, air and the environment (Setiyono, 2014). There are several factors cause the chemical pollution of water, namely the nature of the soil or water quality, pollution of raw water treatment, at the time the screening process or material that direct contact with drinking water, filtration methods and equipment used (the WHO, 2011 and Adelina et.al., 2012). Unlike the microbial contamination may result in acute contamination, chemical compound causes latent health problems due to exposure to certain chemicals that constantly. Contamination may have occurred many years before the health problem is detected (Adelina et.al., 2012).

\section{E. Conclusion}

1. The value of the MPN in drinking water drinking water depot refill Tulungagung district amounted to $59.55 \%$ qualified. This indicates that from 89 samples processed water depot refill drinking water the majority of purity are not eligible.

2. Levels of $\mathrm{Mn}$ in air results in processed drinking water depot refill Tulungagung district averages - average of $0.10 \mathrm{mg} / \mathrm{l}$. minimum Levels of $\mathrm{Mn} 89$ samples of processed water amounted to 0.04 $\mathrm{mg} / \mathrm{L}$ and the maximum levels of $0.19 \mathrm{mg} \mathrm{Mn} / \mathrm{l}$. From those results show that 89 samples processed water depot drinking water refill Tulungagung district all meme nuhi terms is chemically.
3. Hygiene sanitation depot drinking water rated from three aspects, namely, the location of buildings and sanitation facilities sanitation. Of these only three aspects of sanitation facilities that have an impact on the quality of the processed water microbiology depot drinking water refill Tulungagung district. This is proved by the results of statistical tests which the $\mathrm{p}$ value $=0.008$.

4. raw water sources used by the depot drinking water refill Tulungagung district the majority (92\%) using raw water source of water of the mountains. Statistically the use of raw water source there is no influence on quality of Microbiology or chemical quality.

5. Hygiene 89 operators of the depot drinking water refill Tulungagung district of $79 \%$ do not qualify. Based on statistical tests do not affect the quality of the operator's hygiene microbiological or chemical quality. This is evidenced by the value of the $p$ value $=0.163$.

6. independent of the variable factors that most influence the quality of Microbiology variable is statistically sanitation facilities. There is no independent variables that affect the quality of chemically processed water depot drinking water refill Tulungagung district.

\section{F. Suggestion}

1. For the community for the community should pay attention to the quality of drinking water recharge into daily consumption. How that can be done among others by knowing the certificate of hygiene or be eligible to list quality test results from the laboratory of the health area that belongs to the depot drinking water. 
e-ISSN: 2614-4921

2. For Health Agencies For health agencies in order to better improve the supervision of the quality of water by conducting regular inspections three months once the processed result to water depot drinking water refill. To the consumer should provide insight into the importance of the quality of the chemical and microbiological drinking water and its impact on health.

3. For the next Researcher To the next so that researchers pay more attention to the research of the variable. In this case the operator hygiene variables become limitations in this study due to the inability of researchers to find out with certainty the actual operator conditions.

\section{Bibliography}

Adakita News. 2015, 5.924 Depo Air Minum Belum Kantongi Sertifikat Hygienis Sanitasi, Diakses 14 Februaru 2017, https://www.adakitanews.com

Alamsyah. 2006, Merakit sendiri alat penjernih air untuk rumah tangga, Kawan Pustaka, Jakarta

Alimul, A.Aziz. 2008, Metode Penelitian Keperawatan Teknik Analisa Data, Salemba Medika, Jakarta

BPOMRI. 2003, Hasil Pengujian Lab Atas Kualitas Air Pada Depo Air Minum Isi Ulang, Diakses 14 Februari 2017, http://www.pom.go.id

Chandra, B. 2007, Pengantar Kesehatan Lingkungan, EGC, Jakarta

Firmanasari. 2015, Jaminan pemenuhan kebutuhan air bersih oleh masyarakat melalui transparansi pengawasan di perusahaan daerah 
Journal for Quality in Public Health

Vol. 1 No. 1 Januari 2018

Teknik Pomits vol. 2, no. 2, (2013) ISSN: 2337-3539

Masduki Ali. 2011, Unit Desinfeksi. Bahan Perkuliahan Pengolahan Air Minum Program Sarjana Teknik Lingkungan Institut Teknologi Sepuluh Nopember (ITS). Surabaya

Notoatmodjo. 2005, Metodologi Penelitian Kesehatan, PT Rineka Cipta, Jakarta

Nuraini. 2015, Analisis Logam Berat Dalam Air Minum (AMIU) Dengan Menggunakan Spektrofotometri Serapan Atom (SSA), Universitas Tadaluko, ISSN: 1412-2375

Sabariah 2015, “Faktor-Faktor Yang Berpengaruh TerhadapCemaran Air Minum Isi Ulang Oleh EscherichiaColi Di Kota DenpasarTahun 2015”, Tesis, Universitas UdayanaDenpasar, Bali

Said, N.I. 2007, Desinfeksi untuk pengolahan air minum, Diakses 23 Februari 2017, https://phish.opendns.com

Setiyono, A. 2014, Studi Kadar Mangan (Mn) Pada Air Sumur Gali Di Desa Karangnunggal Kecamatan Karangnunggal Kabupaten Tasikmalaya, Jurnal Kesehatan Komunitas Indonesia, UNSIL, Tasikmalaya
p-ISSN: 2614-4913

e-ISSN: 2614-4921

Soedarto. 2013, Lingkungan dan kesehatan, sagung seto, Jakarta

Soedarto. 2013, Lingkungan dan Kesehatan, Sagung seto, Jakarta

Soemirat. 2011, Kesehatan Lingkungan, Gadjah Mada University Press, Yogyakarta

Sugiyono. 2008, Metode Penelitian Bisnis, Alfabeta, Bandung.

Suprihatin. 2008, Higiene Sanitasi Depot Air Minum Isi Ulang Di Kecamatan Tanjung Redep Kabupaten Berau Kalimantan Timur, Jurnal Kesehatan, Kalimantan

Sutrisno, dkk. 2006, Teknologi Penyediaan Air Bersih, PT Rineka Cipta, Jakarta

Widiyanti. 2004, Analisis Kualitatif Bakteri Koliform Pada Depo Air Minum Isi Ulang di Kota Singaraja Bali, Jurnal Ekologi Kesehatan Vol 3 No 1

Widowati, dkk. 2008, Efek ToksikLogam, Penerbit Andi, Yogyakarta 